\title{
The Fight of the Comedian: Comedy as the Arena of Philosophical Thought in Society
}

\author{
Yossra M. Hamouda \\ Philosophy Department, The American University in Cairo (AUC), Cairo, Egypt \\ Email: yossrahamouda@aucegypt.edu
}

How to cite this paper: Hamouda, Y. M. (2019). The Fight of the Comedian: Comedy as the Arena of Philosophical Thought in Society. Open Journal of Philosophy, 9, 318-330.

https://doi.org/10.4236/ojpp.2019.93021

Received: June 12, 2019

Accepted: August 5, 2019

Published: August 8, 2019

Copyright ( 2019 by author(s) and Scientific Research Publishing Inc. This work is licensed under the Creative Commons Attribution International License (CC BY 4.0).

http://creativecommons.org/licenses/by/4.0/

(c) (i) Open Access

\begin{abstract}
Aristophanes describes The Clouds as "the wisest" of his comedies. The choice of wisdom as an attribute of comedy seems strange because the common perception of comedy understands it to be concerned with the absurd and the ridiculous. Wisdom is associated more with philosophy. This paper argues that comedy is an arena for philosophical ideas in society. This paper traces the ancient Greek philosophical fight of Aristophanes and Socrates and its manifestation in the arena of comedy within the two comedies The Clouds and The Cynics' way of life. In this paper, there are also examples from the Egyptian comedian theatre like The Married, Imprison Your Daughters and It Is Truly a Very Respectful Family and the Egyptian comedian media like Al Hudood mock news website. The analysis of these examples supports the claim that comedy is the arena of philosophical thought in different societies and times (not only in ancient Greece). The larger aim of this paper is to examine the philosophical potential of comedy and its effect within the realm of ideas in society.
\end{abstract}

\section{Keywords}

Comedy, Philosophy, Socrates, Aristophanes, The Cynics, Egyptian Comedy

\section{Introduction}

"Truth's a dog must to kennel; he must be whipp'd out..." said the Fool of King Lear.

In Sam Hall's book Shakespeare's Folly: Philosophy, Humanism, Critical Theory, (Hall, 2016) argues that the Fool in Shakespeare's plays is an important figure in the history of Western Philosophy and that the Fool is part of a long philosophical tradition of what he calls "the philosopher-fool". He places three important philosophical figures in this tradition (Socrates, Montaigne and 
Nietzsche). The theme of Hall's book is interesting because it shows a possible relationship between comedy and philosophy that can be tracked in both literary and philosophical works and figures. For Hall, the Fool in Shakespeare (a literary figure) and Socrates (a philosophical figure) are both philosophers and comedians at the same time.

This paper analyzes the relationship between comedy and philosophy and tries to examine an important point in the history of philosophy in which comedy was the arena for the fight of philosophical ideas in society. This paper examines the fight in ancient Greece between the protection of conventional ideas and religion against the Socratic Method's critique of these institutions. The arena for this fight is Aristophanes' The Clouds and The Cynics sarcastic critique of the foundations of ancient Greek society through their confrontational way of life.

Socrates is considered the founder of Western philosopher therefore; the first section of this paper will examine Socrates as both a comedian and a philosopher who challenged the established conceptual institutions of the Ancient Greek society.

\section{Ancient Greek and Roman Comedy}

\subsection{Socrates (Critique of Established Conceptual Institutions) vs. Aristophanes (Protection of Conventionality)}

\subsubsection{Socrates (The Critique of Established Conceptual Institutions)}

In Alain De Botton's book The Consolations of Philosophy, De Botton chooses Socrates as the philosophical model that should teach us to disregard the point of view of the majourity and to believe in what logic teaches us as true regardless of the cost (De Botton, 2000). De Botton speaks about what he considers the most important and influential trait in Socrates' personality: "But his most curious feature was approaching Athenians of every class, age and occupation and bluntly asking them, without worrying whether they would think him eccentric or infuriating, to explain with precision why they held certain sense beliefs and what they took to be the meaning of life". For De Botton, this trait is subversive because it endangers the popular undoubted fundamental beliefs. This trait caused Athenians to fear Socrates and threaten him with death. De Botton also mentions Aristophanes' comic critique of Socrates. De Botton reads Aristophanes' The Clouds as a work that helps Athenians keep their security towards their foundational ideas that are attacked by Socrates. De Botton views Aristophanes as a defender of conventional thought, ordinary explanations and popular beliefs against The Socratic Method.

De Botton chooses two dialogues to convey through them The Socratic Method (Laches and Meno) and De Botton reads Laches as a critique of associating courage with military life alone. Later, De Botton specifies six steps for applying The Socratic Method: 1) choosing a statement that is widely accepted. 2) Searching for exceptions to the statement 3 ) If there is an exception, the statement is not true. 4) The statement should be modified to account for the excep- 
tion. 5) If the new statement still contains an exception then the process should be repeated. 6) The result of thought is higher than the result of intuition.

De Botton's ideas and analysis of The Socratic Method in Laches does not tackle few important themes in Laches that are extremely relevant for understanding The Clouds. Laches is a dialogue on the definition of courage but it is also concerned with the education of the youth. Lysimachus is a military figure in the dialogue but he is also a father who cares about his son's education and would like to know whether the military education will benefit his son or not. Socrates is a model of thought for the education of youth in the dialogue. Socrates does not appear as disrespectful to the elder patriarchal figures as he humbly states his inferiority to them and asks them to teach him about their knowledge of courage first. When Nicias and Laches speak, he does not try to side with anyone but rather respects both of their points of view. Socrates makes Laches admit his lack of knowledge about courage through Socrates persistent questions on Laches' definition of courage. Despite defeating Laches, Socrates does not give an alternative definition for courage. Socrates' triumph in Laches is his success in convincing the elder patriarchal figures to go to school again. This success can be lost on the modern reader because of the difference in culture. Yet, in a patriarchal military society, the patriarchal military figure is an ideal human being that does not need further completeness. Laches' end is extremely subversive because it shows that the most respected figures of ancient Greek society (military figures and fathers) need education as well. It also shows that one of the most foundational virtues (courage) needs to be questioned and redefined.

Another example of The Socratic Method and its strong critique of social and religious foundations is The Symposium. In The Symposium, Socrates makes a very strong statement by denying the divinity of Eros and defending the point of view that Eros is neither human nor God. Socrates also makes another strong claim in The Symposium. Socrates claims that Eros is a lover of wisdom (a philosopher). These claims help us in understanding how Socrates was not afraid even to deprive a God of its divinity because he places the love of wisdom (philosophy) above the divinity of Eros.

\subsubsection{Aristophanes' Clouds (Protection of Conventionality)}

Aristophanes said: "This comedy is the most intelligent of all my plays...This comedy has come hoping she can find somewhere in here, spectators as intelligence". In another translation the word "intelligent" can be replaced by "wise." What Aristophanes meant is extremely important because he connects his comedy to wisdom. Wisdom is the end of philosophy and therefore, Aristophanes envisions a relationship between comedy and the formation of ideas. Aristophanes wants his audience to engage with his comedy and to be able to reflect on it and form deeper ideas from it.

The main target of the Clouds is to attack Socrates. Aristophanes wants to fight The Socratic Method that attacks conventional morality, religion and established common sense. Aristophanes views Socrates as a threat and wants to 
warn The Athenians of him and his ideas. In Strepsiades, Socrates and the Abuses of Intellectualism, Peter Greenreads Aristophanes as attacking Socrates on descending from heaven and abandoning his "airier pretensions" (Green, 1979). Green is not mistaken in this analysis but what Aristophanes critiques is different. Aristophanes' problem with Socrates' descendence has to do with Socrates' impact on everyday people. Aristophanes' choice of Strepsiades and Pheidippides to play the role of Socrates' students has a reason. Aristophanes wants to choose models of people who only care about material goods. His point is that most people who will become the students of Socrates will not really believe in his ideas but rather will abuse his ideas to destroy all institutions like religion, morality and law. In The Enemies of Socrates. Piety and Sophism in the Socratic Drama; Kenneth C. Blanchard argues that Aristophanes draws in The Clouds the image of an immature Socrates who does not understand that philosophy can be dangerous if it is widespread among the masses (Blanchard, 2000). Blanchard claims: "In Aristophanes' Clouds, Socrates is presented as dangerously naïve... philosophy must be disguised or at least artfully represented, in order to mitigate tension between the philosopher and the city; that philosophy in its undisguised essence is corrosive of piety and morality". Here, Blanchard shows how Aristophanes views Socrates and his Socratic Method that makes philosophy accessible to the masses as dangerous and destructive.

In the Thinkery, students do not care about any material goods and prefers thought to food, cleanliness and luxurious life. Aristophanes does not accuse Socrates of desires; he even mocks Socrates' minimalism. Aristophanes rather argues that the people who have desires that control them will abuse The Socratic Method to destroy all the foundations of morality and law and to gain unfair privileges without even believing in the ideas of Socrates. Strepsiades still swears by Poseidon despite being taught not to believe in religion and claiming to do so. Aristophanes' critique of thought and speech has two reasons; the first of them is that thought and speech can defend anything whether just or unjust; "They become anything they want".

The second reason for Aristophanes' rejection of thought and speech is its inferiority and uselessness compared to violence. One of Nietzsche's main ideas in Twilight of the Idols is to contrast Socrates' speech and thought to Athenian's violence and to consider Socrates a turning point towards the rejection of violence and the triumph of thought. Nietzsche claims: "With Socrates, Greek taste takes a turn in favor of dialectic. What is really happening there? Primarily, a noble taste is thereby defeated; with dialectic, the rabble rises to the top. Before Socrates, dialectical manners were rejected in good society. They were taken to be bad manners, they were a compromising exposure... Dialectic is chosen only as a last resort. It's well known that it creates mistrust that it is not very convincing. Nothing can be wiped away more easily than a dialectician's effect: this is proven by the experience of every gathering where people speak. It can only be self-defense in the hands of those who don't have any other weapons. One needs 
to get one's rights by force; otherwise, one makes no use of it. This is why the Jews were dialecticians; Reynard the Fox was one: what? And Socrates was one too?"

Aristophanes understands this about Socrates and he attacks it strongly. $\mathrm{He}$ claims that speech is not for strong people who want to really work and fight: "they're heavenly Clouds, great goddesses for lazy men-from them we get our thoughts." Here, Aristophanes draws a connection between using speech and being lazy. For Aristophanes, the strong and active individuals do not resort to speech.

Aristophanes connects institutions together; he thinks that religion, tradition, morality, law, military power and patriarchy are related. For him, Socrates is not only a threat to religion and tradition but also to morality, law and patriarchy because they are all connected and they are all forms of power that get challenged by reason and speech. Aristophanes tries to grab the attention of the audience to the danger of refuting religion and tradition by reason. He wants to make the audience aware that the loss of religion and tradition in front of reason will endanger their own positions as fathers in their families. The connection between religion, tradition, morality, law, military power and patriarchy appears a lot in the play but the most important points in which their connection becomes clear occurs in the fight of the speeches and in Pheidippides defense of his right to beat his father. The father who accepts to abandon his religion and chooses reason suffers later when his son destroys the basis of his parental authority also by reason. In the fight of the speeches, the Just speech defends the use of force in education of the young, military education, developing a strong body, respect for fathers, extreme submissiveness to them, avoiding money and inappropriate sexual practices. Aristophanes here chooses to make the Just equivalent to a way of life that values everything that is conventional, powerful and masculine. Also, Aristophanes directly connects the conventional to the just and the new to the unjust. The unjust argument describes itself by saying: "I was the very first of them to think of coming up with reasoning against our normal and just decrees." In this line, the "normal" is equated with the "just." Also, the unjust argument says regarding the just argument: "I'll shoot it down with brand-new expressions and some fresh ideas." Here, Aristophanes hints at the relationship between novelty and falsehood.

Aristophanes' comical presentation of traditional values and novel ideas points to the author's desire to ignite fear and hatred towards Socrates among the public Athenians. He wants to make them view Socrates' attack on religion and tradition as a threat to their authority over their sons. Aristophanes wants to play on the Athenian fathers' fear of their sons' disobedience because of Socrates' destruction of authority. When Pheidippides uses argumentation to establish his right to beat his father, Strepsiades relates his loss of authority over his son to Zeus' loss of his worship as a patriarchal figure. He tries to protect his patriarchal power by returning to Zeus, telling his son: "You must. Revere Parental 
Zeus." When Strepsiades realizes that Socrates' ideas deprive him from his parental authority because they deprive Zeus from his divinity, he decides to burn the Thinkery. While burning the Thinkery, he warns the audience against Socrates and indirectly encourages them to attack Socrates. Here, Aristophanes indirectly encourages the Athenians to kill Socrates. Aristophanes achieves his desire after more than twenty-four years and Socrates is sentenced to death. The Clouds was written in $423 \mathrm{BC}$ and Socrates died by drinking poison in $399 \mathrm{BC}$. Socrates was stabbed to death by The Clouds on the arena of Athenian comedy.

\subsection{Aristophanes (Protection of Conventionality) vs. the Cynics' Way of Life (Rebellion against Conventionality)}

Did the Socratic Method lose on the arena of comedy by the time of Socrates' death? The answer is "No." When Socrates dies, his student Antisthenes establishes one of the most important philosophical schools that use comedy and comic syllogism to argue against conventional religion, tradition, morality and patriarchy The Cynics. The Cynics are not only philosophers but also comedians who know well how to fight the impact of The Clouds both in the realm of philosophy and in the arena of comedy. The Cynics way of life is a rebellion against all the institutions that Aristophanes tries to defend in The Clouds. The Cynics rebellion is an answer to the burning of the Thinkery in The Clouds' end. Their way of life shows that Socrates' death does not protect conventionality and does not lead to the death of his ideas.

John MacCunn in his article The Cynics states clearly that The Cynics should be regarded as both philosophers and satirists and this should not make us disregard them as mere "spiritual clowns" (MacCunn, 1903). MacCunn tries throughout his article to track the relationship between The Cynics and Socrates and to compare their way of life and ideas to the way of life and ideas of Socrates. For MacCunn, the Cynics' way of life is inspired by Socrates and they hold a certain interpretation of Socrates that differs from Plato. The Cynics understand Socrates to be both personality and doctrine and they understand that Socrates (unlike Plato and Aristotle) is not obsessed with reason and rationality and more interested in the will.

MacCunn thinks that the Cynics are different from Socrates. Socrates searches for definitions while the Cynics are not concerned with finding them. More importantly, Socrates respects the laws of ancient Greece and pays his life for this respect while the Cynics rebels against those laws and rejected all forms of social life. The Cynics reject the rules of the Athenian society and view these laws as counter to natural law and they consider the natural law superior to any other law. They reject slavery and fight for moral freedom: MaCcunn even claims that The Cynics are far advanced compared to Plato and Aristotle in cosmopolitanism. For MacCunn, The Cynics lack a supreme principle:

"For when philosophy or science demands self-dedication to the theoretic life, it is not barren of most practical results. It is of the very essence of it 
that it brings the finite individual life into conscious relation to a supreme Realty - call it Idea of the Good, Infinite Sub stance, the Absolute, Dens sive Natura-which, in Spinoza's language, can fill the soul entirely...From this source of strength the Cynics were cut off. In their struggle after an absolute moral independence, in their narrowly practical concentration upon this, they turned away, with fatal blindness, from the perennial sources of individual strength. So will it ever be with all who follow them in magnifying the moral life to the neglect or disparagement of a religious faith or a speculative philosophy."

Here, MacCunn is mistaken because The Cynics believe in a natural law that has supremacy over any human law or religion and even if this natural law is not a sufficient supreme principle this should not be viewed as a weakness. The real strength of the Cynics lies in their rebellion against all higher institutions. The Cynics will be inauthentic if they establish a supreme principle.

Towards the conclusion of his article, MacCunn stresses on the power of the Cynics' comedy:

"Cynics made war upon the world in the most effective way. Human nature will endure, and even welcome, satire and combination, especially when humorous. Satire is good reading, and the masters of invective, Juvenal, Swift, Carlyle, are far from unpopular. But there is nothing which so effectually turns the edge of invective as the perception that it is undiscriminating."

Another important article on the Cynics' impact on the ancient world is Thomas W. Africa Stoics, Cynics and The Spartan Revolution. In this article, Africa argues that the difference between the Cynics and the Stoics lies in the Cynics' rejection of property and their insistence on a deprived harsh life which makes them freer than the Stoics (Africa, 1959). Africa argues that the Cynics are more focused on their personality rather than their thought. He mentions Cercidas the Cynic and how he accuses religion of protecting the rich centuries before Marx's "opium of the masses." Cercidas calls Zeus "a real father to some but only a step-father to others." Africa even concludes that the Cynics are the philosophical inspiration of the Spartan Revolution. Cercidas' statement shows that the Cynics view laws, conventional morality and religion as only forms of protection to the rich and the stronger. For the Cynics, these institution are not natural but rather ways of protecting the stronger in the society.

The Lives of Eminent Philosophers for Diogenes Laertius was written in 300 A.D. It is the best source for understanding the Cynics because it is one of the sources that give us an image about different philosophers in their everyday lives and not in their written philosophy. This approach is specifically beneficial to us in understanding the Cynics because most of them view philosophy more as a lived life rather than a written discipline. In this aspect, they follow their master Socrates.

The Cynics reject all institutions even the social ones like marriage; Antis- 
thenes and Diogenes both attack marriage. There is an exception to this rejection of marriage once in the known history of the Cynics which is the marriage between Hipparchia and Crates. Hipparchia is one of the very few female philosophers we know about in the ancient world. In Kathleen Wider's paper Women Philosophers in the Ancient Greek World: Donning the Mantle, Wider argues that women played an important role in ancient philosophy but both the modern and the ancient sources do not give us enough information about them because of sexism (Wider, 1986). Wider mentions in her paper important ancient female philosophers like Aspasia, Diotima, Hypatia, Arete, Pamphile, the women Epicureans and Hipparchia.

According to Diogenes Laertius; Hipparchia submits to marriage as a social institution but she fights patriarchy and all the social conceptions of appropriate behavior. She loves Crates who is years older than herself and leaves all his money behind him to pursue the destitute life of a Cynic philosopher. She insists on marrying him despite all the pressure from her parents and the rejection of even Crates himself. A lot of rich and young good looking men propose to her but she rejects them and insists to marry Crates and when her family uses Crates to convince her to leave him, she threatens to commit suicide if she does not marry him. In this age, we may consider Hipparchia's behavior crazy love but in the type of patriarchal society in which she lives, her decision and insistence on marrying the man she loves even if it costs her life is a revolutionary act against society. Hipparchia's rebellion against her patriarchal society does not end by her marriage to Crates; it rather starts. She pursues a Cynic life and abandons all her luxury. She becomes a philosopher and attends the symposiums where philosophical discussions occur. When Theodorus rejects her attendance to a symposium, she uses the Cynics weapon to defend her right; she uses a funny syllogism:

"Any action which would not be called wrong if done by Theodorus would not be called wrong if done by Hipparchia. Now Theodorus does no wrong when he strikes himself, therefore neither does Hipparchia do wrong when she strikes Theodorus."

Theodorus does not submit to Hipparchia's argument and tries to strip her. Hipparchia does not show any embarrassment like other women. This reaction proves that she is a true Cynic who challenges patriarchy as a social order and all ideas of appropriateness in society. The challenge of appropriate social behavior is one major trait of the Cynic life. Crates is known as the "Door-opener" because he opens every door he finds. The Cynics never care for their looks: Crates sews sheep skin to his cloak. They do not care also about society's hierarchies; Menippusis a slave and Antisthenes (the founder of The Cynics) is not fully Athenian.

The Cynics reject money. Crates is born rich but he donates all his money. It is even said that Crates leaves his money in the hands of a banker and orders the banker to ask his children when they mature whether they want to pursue a philosophical life or not so that they can choose between money and philosophy. 
Diogenes views money as a barrier to happiness and he calls rich people "the sheep with the golden fleece"and when he is asked about the reason for gold's pale colour, he answers: "it has many thieves plotting against it." One of Diogenes' main critiques of Plato is Plato's luxurious way of life and pride. When Plato invites him to his house for dinner, Diogenes rolls on the carpet and says: "I trample on Plato's vain glory."

The real strength that allows the Cynics to defy all laws of society is their disbelief in all forms of power and control and their belief in freedom. They never give weight to the majourity's opinion of them. They mock even the institution of religion: When Athenians ask Diogenes to be "initiated", he answers mockingly: "It would be ludicrous if Agesileus and Epaminondas are to dwell in the mire, while certain folk of no account will live in the Isle of the Blest because they have been initiated." He even mocks the people who perform purification: "Unhappy man, don't you know that you can no more get rid of errors of conduct sprinklings than you can of mistakes of grammar?” Diogenes devaluates the importance and impact of religious rituals like initiation and purification. $\mathrm{He}$ states that they cannot be a way to a better position in front of the Gods without moral personality and actions.

The Cynics attack philosophical doctrines raising doubt in them. When Diogenes hears someone talking about the Celestial world he asks him: "Were you in coming from the sky?" Plato receives tremendous attacks from Antisthenes and Diogenes. When Plato calls the human being "an animal, biped and featherless", he is well-regarded. Diogenes answers Plato's statement by comedy. Diogenes brings a plucked fowl into Plato's lecture and says: "Here is Plato's man."Diogenes' extensive attack on Plato makes Plato call him a dog. Diogenes answers Plato's offence by this statement: "Quite true for I come back again and again to those who have sold me."The Cynics are known as dogs. This name may refer to their deprived and ugly way of life but it may also refer to their character as emotional, authentic and loyal. The Cynics try to be independent even from their natural needs. They want to be stronger than their natural human weaknesses. Diogenes walks on snow and tries to eat meat without cooking. In winter, he hugs statues covered in snow and in summer, he tortures himself by rolling in his metallic pipe. He tries to defeat his bodily weaknesses.

The Cynics defeat their bodily needs but they maintain their emotional need for the other. Hipparchia maintains her extreme love and need to Crates. When Diogenes is threatened death by Perdiccas, he tells him that he does not fear death but he fears that Perdiccas will be happy without him. For Diogenes, being killed is something that he fears less than being abandoned by the other.

The Cynics have no fear of political power which is one of their most important traits that allow them to live up to their ideas. When Alexander the Great asks Diogenes to make any wish, Diogenes simply answers: "Stand out of my light." Even when Diogenes is told that the people of Sinope sentences him to exile, he answers: “And I sentenced them to home-staying."Diogenes does not 
submit to slavery as a world system. When he is caught and sold as a slave to Xeniodes, he tells Xeniodes that he should obey Diogenes: "You must obey me, although I am a slave for if a physician or a steer man were in slavery, he would be obeyed". He is not afraid of being beaten or tortured by his master. He courageously confronts his master and states that he is the one who must be obeyed. He reverses the power structure between a master and a slave. In slavery; he never seizes to be free from fear and submission.

\section{The Modern Egyptian Comedy}

This section of the paper tries to establish that the relationship between comedy and the philosophical ideas in society is not exclusive for the ancient Greek society. This section examines examples of comedy as an arena for philosophical ideas in the Egyptian society. The first example of Egyptian comedy used is the Egyptian Theatre. Comedy plays a very crucial role in the Egyptian Theatre. In Samah Masoud's The Marriage between Enjoyment and Thought in the Egyptian Theatre-Studio 80 Team as an Example, Masoud states that the Egyptian audience has a strong passion for theatre. She distinguishes between two types of theatre in Egypt: "The Commercial Theatre" and "The Thought Theatre" (Masoud, 2015). She chooses to use the theatrical group Studio 80 as her example of what she identifies as "Thought Theatre."

If we search for Thought in other examples of the Egyptian Theatre-other than Studio 80 Team -we will find a considerable amount of works that mock the most fundamental social ideas in Egypt. It Is Truly a Very Respectful Family and Imprison Your Daughters are two important plays in the history of the Egyptian Theatre that critique the methods of education in the Egyptian families. Fouad El Mohandes (a well-known Egyptian comedian) plays the main character in both plays. It Is Truly a Very Respectful Family tells the story of a very conservative father who controls his family by force, fear and totalitarian ideas until he marries a dancer. The dancer's personality and ideas contradict those of the conservative family. She succeeds in changing the way the family members think and leads them to rebel against the controlling father. The play is a critique of traditional family morals. It tries to convey that the dancer can be more qualified as a parent than the conservative governmental employee (the father). Imprison Your Daughters also discusses the education of the young but it is more focused on the oppression that is exerted by the fathers on their daughters. This play is a strong statement against patriarchy through comedy.

The concept of Happiness and how it relates to owning money is also an important theme in the Egyptian comedy. The Married is about two poor men who marry rich women to seek happiness but they fail to be happy. They only reach happiness when they leave the luxurious life and return back to their past poor and honest life. Political ideas and critique of totalitarian corrupt presidents also is a main theme in the Egyptian Theatre. The two works Divagations and The Leader are two strong comic critiques of totalitarian corrupt systems. 
Another interesting example of comedy in Egypt-other than theatre-is a comic news website called Al Hudood. What is interesting about this news website is how it plays with our conceptions of reality and comedy. A news website should be a place where one finds truth. Journalism is concerned with publishing "true" news pieces that represent reality in the most accurate way possible. Al Hudood's mission is the exact opposite of this. Al Hudood states clearly that the news pieces published on its website are only imaginary news stories that mock reality. Al Hudood's main target is to show through these fake news pieces how our reality is more ridiculous than comic imagination.

These are few examples of headlines from Al Hudood:

"A lucky child is born to a family that believes in the right religion."This headline mocks a famous well-established idea among the Egyptian Muslims that they are lucky to be born Muslim and to be in no need to change their religion in order to go to heaven. Another example of mocking religious ideas in $A I$ Hudood is this headline: "A Young Man embraces Islam, Christianity and Buddhism together just in case any of them is true." In Egypt, Muslims and Christians speak about the necessity of believing in Islam or Christianity because the believer will not lose anything if God is not true but the non-believer will be tortured in Hell if God is true. Al Hudood mocks this argument in this headline.

The political mockery in Al Hudood is targeted both towards the Egyptian and international political systems. This is a headline about the Egyptian Constitutional Amendments that allow Sisi to continue as a president for another twelve years: "Sisi votes 'Yes' for The Constitutional Amendments for the Sake of Egypt Despite of His Hatred and Lack of Trust To The Current President." This headline makes fun of Sisi's supporters who claim that they support Sisi for protecting Egypt even if they believe that he is a failed president. An example of a mock international news piece on Al Hudood is this headline about Trump: “Trump Damns His Luck for Becoming the President Because He Was Forced to Condemn an Amazing Attack like News Zealand's Attack”. Here, Al Hudood makes fun of Trump's right wing political agenda.

The most interesting section of Al Hudood is the section titled "We Wish It Was Al Hudood." In this section, Al Hudood presents real news pieces. This section tells the reader the subversive message of $A l$ Hudood that reality is more ridiculous than comedy and imagination. These are examples from this section:

“Bashar El Assad: The Region's Destiny Is Only Chosen by the Region's People."

"Sisi: Whenever I Find Someone Who Is Overweight, I Say That He Does Not Work."

There is a very interesting case that happened with Al Hudood:

"Sisi Confirms To the Egyptian Youth That He Will Certainly Leave The Presidency Because He Will Not Live Forever."

"Sisi: There Is No Ruler Forever. Every Human Being Dies. Therefore, The 


\section{Ruler Will Not Remain 100 Years Or 200 Years.”}

The first headline was published in Al Hudood as a mock news piece in July 2018 while the second news piece was published in November 2018 as a real news piece in different Egyptian news websites. Here, we find ourselves in front of a case in which comedy predicts reality. It is more than a coincidence. Comedy has a mysterious mesmerizing relationship to both reality and thought. This paper examined the relationship between comedy and philosophical thought but it remains for other scholars to examine the relationship between comedy and reality.

\section{Conclusion}

This paper presented and analyzed examples of comedy as the arena of philosophical ideas in society. The philosophical fight between Aristophanes and Socrates on conventionality was analyzed in both The Clouds and the Cynics' way of life. The paper offered a reading of The Clouds as a defense of conventionality and an attack on change and novelty. It supported the claim that the Cynics' way of life challenged conventionality even after Socrates' death. It also presented examples from the modern Egyptian comic theatre and media. The analysis of these examples showed that comedy was an arena of philosophical ideas in different times and societies.

\section{Conflicts of Interest}

The author declares no conflicts of interest regarding the publication of this paper.

\section{References}

A Lucky Child Is Born to a Family That Believes in the Right Religion. Al Hudood. http://alhudood.net/9436/رضيع-محظوظ-يو لد-لأهل-يؤمنون-بالدين_الص

A Young Man Embraces Islam, Christianity and Buddhism Together Just in Case Any of Them Is True. Al Hudood. http://alhudood.net/18044/شاب-يعتنق_الإسلام-و المسيحية-و البوذيّي

Africa, T. W. (1959). Stoics, Cynics, and the Spartan Revolution. International Review of Social History, 4, 461-469. https://doi.org/10.1017/S0020859000001462

Bashar El Assad: The Region's Destiny Is Only Chosen by the Region's People. Al Hudood. http://alhudood.net/24532/ليتها_الحدود-بشار -الأسد-مصبر -المنطقة

Blanchard, K. C. (2000). The Enemies of Socrates: Piety and Sophism in the Socratic Drama. The Review of Politics, 62, 421-449. https://doi.org/10.1017/S0034670500041644

De Botton, A. (2000). The Consolations of Philosophy. London: Hamish Hamilton.

Green, P. (1979). Strepsiades, Socrates and the Abuses of Intellectualism. Byzantine Studies, 20, 15-25.

Hall, S. (2016). Shakespeare's Folly: Philosophy, Humanism, Critical Theory. Abingdon-on-Thames: Routledge. https://doi.org/10.4324/9781315622637

Imprison Your Daughters. Directed by Fouad El Mohanndes. Cairo.

It Is Truly A Very Respectful Family. Directed by Othman El Hamamsy. Cairo. 
Maccunn, J. (1903). The Cynics. International Journal of Ethics, 14, 185-200.

https://doi.org/10.1086/206051

Masoud, S. (2015). The Marriage between Enjoyment and Thought in Egyptian Theatre: Studio 80 Team as an Example. Childhood and Education Journal, 7, 123-145.

Sisi Confirms to the Egyptian Youth That He Will Certainly Leave the Presidency Because He Will Not Live Forever. Al Hudood.

http://alhudood.net/17335/السيسي-يؤكد_للثباب_المصري_أنه-بالتأكي_Al

Sisi Votes "Yes" for the Constitutional Amendments for the Sake of Egypt Despite of His Hatred and Lack of Trust to the Current President. Al Hudood.

http://alhudood.net/24631/السيسي-يصوت_للتعديلات_الدسنورية_-بنع

Sisi: Whenever I Find Someone Who Is Overweight, I Say That He Does Not Work. Al Hudood.

https://alhudood.net/24803/\%d9\%84\%d9\%8a\%d8\%aa\%d9\%87\%d8\%a7-\%d8\%a7\%d9\% 84\%d8\%ad\%d8\%af\%d9\%88\%d8\%af-\%d8\%a7\%d9\%84\%d8\%b3\%d9\%8a\%d8\%b3\%d9\% 8a-\%d8\%a3\%d9\%88\%d9\%84-\%d9\%85\%d8\%a7-\%d8\%a8\%d8\%a7\%d9\%84\%d8\%a7\%d9 \%82\%d9\%8a-\%d8\%ad\%d8\%af-\%d9\%88

The Leader. By Farouk Sabry. Directed by Sherif Arafa. Cairo.

The Married. By Faisal Nada. Directed by Hassan Abdel Salam. Cairo.

Trump Damns His Luck for Becoming the President Because He Was Forced to Condemn an Amazing Attack like News Zealand's Attack. Al Hudood. http://alhudood.net/23590/بلعن_الساعة_التي-صرت_فيها-رئيساً_مضطر

Wider, K. (1986). Women Philosophers in the Ancient Greek World: Donning the Mantle. Hypatia, 1, 21-62. https://doi.org/10.1111/j.1527-2001.1986.tb00521.x 